\title{
An Ethical Roadmap for Prioritizing Medical Resources Within Muslim Societies During the COVID-19 Pandemic
}

\author{
Qosay A. E. Al-Balas ${ }^{1}$ D . Wael K. Al-Delaimy ${ }^{2}$
}

Accepted: 8 July 2021 / Published online: 17 July 2021

(C) The Author(s), under exclusive licence to Springer Science+Business Media, LLC, part of Springer Nature 2021

\begin{abstract}
Profound ethical challenges have been generated by the emergence of the COVID19 pandemic. The unprecedented plights that have arisen have led nations to devise ethical roadmaps for handling their finite resources. Muslim countries are no exception and must continue to endure the effects of the pandemic, as more waves of infections from new strains are being reported. Given the scarcity of resources available to some countries, it is critical to adopt a roadmap to prioritize these limited resources based on ethical guidelines that are acceptable to Muslim communities. This work describes the concept of "ijtihad", a process frequently used by Muslim scholars to develop novel solutions to deal with unprecedented events, such as the recent pandemic. In this manuscript, Islamic perspectives were discussed on social justice and equality and how limited resources can be used in a way consistent with such perspectives. Relying on previous experiences of the Muslim community, such as the plague of Amwas, in which social distancing and quarantine strategies were used effectively to control the disease, and utilizing available guidelines such as "AlQawaid Al-Fiqhiyyah" and "Fiqh Al-Nawazel", we propose a practical protocol and roadmap that can be applied in the current crisis. Managing and prioritizing limited medical resources requires a just and ethically acceptable system. Islamic leaders should immediately develop a roadmap that emphasizes ethical values such as ihsan and altruism to help Muslim countries prioritize the limited medical resources available to medical staff to guarantee the sustainability of health services.
\end{abstract}

Qosay A. E. Al-Balas

qabalas@just.edu.jo

Wael K. Al-Delaimy

waldelaimy@ucsd.edu

1 Department of Medicinal Chemistry and Pharmacognosy, Faculty of Pharmacy, Jordan University of Science and Technology, Irbid, Jordan

2 University of California San Diego, 9500 Gilman Dr. MC 0628, La Jolla, CA 92093 0628, USA 
Keywords Ijtihad · Al-Qawaid Al-Fiqhiyyah · Fiqh Al-Nawazel · COVID-19 pandemic

\section{Introduction}

The World Health Organization (WHO) officially declared COVID-19 a pandemic on the $11^{\text {th }}$ of March 2020 because it had spread to 118 countries, and the number of cases reached 118,000 according to WHO statistics (https://www.who.int/). At the time of writing, the number of cases has surpassed 116 million in more than 192 countries/regions (CSSE, 2021). The pandemic has overwhelmed health sectors in many developed countries worldwide, such as Italy, Spain, and the US, forcing them to adopt guidelines that aim to ensure the fair allocation of medical resources during the pandemic (Emanuel et al., 2020).

All Muslim countries, with a combined population of over one billion, are classified as developing countries, and the health sectors in many of these countries are struggling and are not comparable to the same sector in developed countries in terms of medical staff readiness and health infrastructure such as hospitals and equipment (Razzak et al., 2011). Most Muslim countries have declared the presence of positive cases of COVID-19, a scenario that will likely overwhelm medical services in these countries. Consequently, there is an urgent need to allocate medical equipment and interventions without causing major conflict or civil unrest among both medical staff and the families of the affected patients.

\section{Background}

The US has suffered shortages of N-95 masks, and medical staff were at one point instructed to reuse them (CDC, 2020). Likewise, in Italy, recommendations were published and approved for the allocation of intensive care treatment in exceptional, resource-limited circumstances (Vergano et al., 2020). South Korea and the United Kingdom have suffered from medical supply shortages as well (Kuhn, 2020; Campbell \& Busby 2020). This unprecedented global shortage of medical supplies in the modern era has increased the pressure on governments to find a quick and satisfactory solution.

Some populations, including Muslim populations, have rejected the international recommendations for precautions that can limit the spread of COVID-19, such as social distancing and quarantining. These communities claim that these events are the "will of God" and should be accepted. If many people become infected with COVID-19 as a result and require hospitalization, what should be done (Hashmi et al., 2020)?

It is essential for decision-makers in Muslim countries to develop ethically acceptable guidelines, or "Fatwa", that regulate resource distribution, particularly that of medical resources, in a way that guarantees that all citizens, regardless of their faith or beliefs, will accept and follow government recommendations to limit the strain on medical resources (Hashmi et al., 2020). The aim of our study is to 
explore the ethical precedents that can be used by Muslim scholars to prioritize medical resources during the COVID-19 pandemic and avoid potential conflicts.

\section{Islamic Ethical and Moral System}

Islam has an ethical and moral system to address scientific advancements and decisions, such as plague management strategies, end of life decisions (Al-Bar $\&$ Chamsi-Pasha, 2015) and the application of genetic engineering (Al-Balas et al. 2019, 2020), in a morally and religiously acceptable manner. The plague of Amwas, which was reported to be the first pandemic to impact the new Muslim empire, occurred in 17-18 Hijri/638-9 A.D. The effects were devastating, and thousands of people died (Bearmand et al., 2002). Quarantine was the only way that Muslims in the area managed to avoid more catastrophic consequences of this disease; the quarantine was ordered by the prophet's companion Amr ibn al- 'As: "O people! when this disease strikes, it flames up like burning fire, therefore, save yourselves from it by taking refuge in the mountains" (Zohaib \& Arzoo, 2021).

Hence, Muslim countries should be proactive in addressing the shortage of health care equipment caused by the COVID-19 pandemic. The highest religious authority which has the jurisdiction of this is the International Islamic Fiqh Academy, which is based in Jeddah and has 57 member states (http://www.iifa-aifi. org/). The most pressing issue in hard-hit countries is how to establish priorities for the use of ventilators and ICU beds. The Fiqh Academy is well respected in Muslim countries, and its decisions are likely to be adopted and accepted by its member states. From this perspective, an ethical nonobligatory roadmap can be introduced by Muslim scholars to help in prioritizing the use of ventilators and determining when it is acceptable to withdraw mechanical ventilation from patients who are not yet declared dead (Yoosefi et al., 2021; Carey et al., 2021). The involvement of Muslim scholars in decisions related to withholding treatment, which can lead to patient death, is critical in Muslim societies.

It should be emphasized that the application of such criteria is only useful in emergency situations and after exhausting all medical options in both the public and private sectors. Moreover, the proposed rationing criteria should be shared with ethical committees, patients, families, and all stakeholders to provide transparency and increase trust in the health care leaders in these countries.

\section{Three Indispensable Islamic Values}

It is worth mentioning that three indispensable Islamic values should be recognized by decision-makers and should not be ignored: justice, altruism (Ihsan) and respect for elderly individuals, all of which are mentioned in jurisprudence sources. For example, altruism is mentioned in the Muslim Holy book, the Quran: "They give them (to others in need) priority over themselves even if they themselves are needy" 
(Abdul-Rahman, 2009). This is relevant to the COVID-19 situation in the context of Islamic culture, where Muslims are expected to be self-sacrificing for the benefit of others. In addition, social justice is mentioned in another verse: "And when you judge between people, judge with justice” (Abdul-Rahman, 2009).

The lack of medical resources during this pandemic is considered a "new" event that was not experienced by early Muslims, and therefore, it is never mentioned directly in the Quran or in the Prophet Mohammad's teachings (Sunna). This places the decision-making burden on what is called the Muslim consensus (Ijmāa $\left.\overline{\mathbf{a}}^{c}\right)(\mathrm{Rabb}$, 2009; John et al. 2014). This consensus follows a broad principle known as ijtihad (an Islamic legal term referring to independent reasoning or the thorough exertion of a jurist's intellect in finding a solution to a legal question), and the outcome of this process is then discussed in a general meeting that includes medical experts and religious scholars. A consensus decision is expected to be issued by this group at the end of the meeting.

\section{ljtihad}

Ijtihad is a large umbrella under which different disciplines can interact to achieve a consensus from the majority members involved in the decision-making. The pillars of ijtihad that are applicable in such emergencies (not necessarily in order of importance) are as follows. First, maslaha (the prohibition or approval of a thing according to necessity and particular circumstances) is used when the decision-maker must choose between one of two choices. There should be a balance between the benefits and risks associated with each choice, and the choice that maximizes benefits and minimizes risks should be selected.

Second, the legal maxims of jurisprudence (Al-Qawaid Al-Fiqhiyyah) are based on five major criteria, each with its own sub criteria. In this case, two major maxims are applicable: the first is "hardship begets facility", which means that any hardship enables decision-makers to make suitable judgments even if it is difficult to accept such judgments in a normal situation. A submaxim derived from this maxim is that "necessity renders all prohibited things permissible", which again gives governing bodies more authority to make responsible decisions regarding the COVID-19 crisis. This might allow us to take a patient off a ventilator if his or her medical status seems hopeless, even if he or she is not already dead, to save another person who needs the ventilator and has a better chance of survival. The other major maxim is that "injury must be removed"; this has many secondary maxims that include "the lesser of two evils is preferred".

Third, the jurisprudence of cataclysms (Fiqh Al-Nawazel) refers to a situation in which a very dangerous and catastrophic event is affecting Muslims worldwide. In this case, the known and established decrees are no longer valid, allowing extraordinary decisions to be made in such emergency situations. Fourth, the jurisprudence of priorities (Fiqh Al-Awlawyat) is an integral cornerstone in the decisionmaking process in extreme situations. There is an obligation for decision-makers to 
prioritize and allocate resources to maximize the benefit of the available resources. Finally, "the theory of emergency cases" is applicable here; although this theory traditionally applies to economic issues during catastrophes, it can be extended to any emergency situation, such as the COVID-19 crises.

Obviously, decision-makers in Muslim countries have a wide range of options for reaching a decision that is satisfactory to all stakeholders in an emergency or exceptional situation such as the COVID-19 crisis. A prominent Islamic scholar in the eleventh century, Ibn Abd Alsalam, once said, "Allah who ordained religion is the same who ordained medicine, so balancing benefits and risks can be done by logic to support the lives of people" (Al-Izz bin Abdul Salam, 2019).

Based on the above discussion, in cases where the limited resources, such as ICU equipment, fall short of meeting the needs of all patients, random selection by lotteries may be a tenable solution. This is supported in Islam, as seen in the case in the Quran of the prophet Jonah, who was randomly selected to be thrown in the sea to save the ship: "Then he (agreed to) cast lots, (to draw lots) and he was among the losers" (Abdul-Rahman, 2009). The advantage of random lottery selection is that it alleviates the tension between the patients' families, who are competing for the scarce medical equipment, and medical staff. Frontline caregivers, who are critical in such medical crises, should have priority access to the scarce resources because they can help save the lives of others. This is supported by the fact that Islam urges logical thinking and reasoning, as mentioned earlier, and that this preferential treatment for such workers is for the larger benefit of the community.

Table 1 Ethical roadmap recommendations

Roadmap initiative

Priority of medical services

Priority of patients

Values

Medical moral reasoning
An Islamic initiative should immediately draft a roadmap to guide Muslim countries in prioritizing limited medical resources. This initiative should be executed by the International Islamic Fiqh Academy, as the group is widely accepted among Muslims and has qualified staff

Priority access to medical services should be given to medical staff, as they are on the frontlines in saving lives

Patients who are more likely to benefit from scarce resources should be prioritized, and this decision should be based on medical expertise

Recognizing the value of altruism and Ihsan should be encouraged within the population, as this will relieve the pressure on medical staff and divert the available resources to the needy

Medical staff should be educated about different kinds of moral reasoning that can help them make appropriate decisions (Model and Kardia 2020). These morals could be taken from the Islamic principles as well as the proposed principles by Childress and Beauchamp (autonomy, beneficence, non-maleficence, and justice) 


\section{Recommendations}

There are several recommendations the authors would like to make based on this paper. These recommendations are presented in Table 1.

\section{Conclusion}

To conclude, Muslim scholars have several options for protecting the public and helping in decision-making during this terrible pandemic. It is essential that decisions be made as a consensus among Muslim scholars and in accordance with the suggestions of medical consultants. This work recommends establishing a triage committee in charge of prioritizing resources, and the committee should work according to transparent and well-known guidelines provided to them by the International Islamic Fiqh Academy, so that patients' families are more likely to accept the outcome as part of the patient's fate chosen for him or her by God. Also, it is believed that to avoid any conflicts, bias, or accusations of unfairness by families and societies, the lottery approach should be followed to select who is put on a ventilator and who is not. This situation is more favorable according to Islamic teaching than a "first come, first served" basis or one based on age or any other criteria. It is important to be proactive and address this issue in advance rather than try to address it in the middle of a health crisis. This is an ethical way to deal with limited resources during a pandemic such as COVID-19 that is in line with the tenets of Islam.

\section{Research Limitations}

The recommendations of this work can be seen as invaluable addition to the Islamic ethical system that regulate the limited resources, especially the medical ones in overwhelming pandemics. The conversion of these recommendations to practical application is the main challenge. Adoption of these recommendation by Islamic organizations and to pursue its application is strongly required to tackle the current COVID-19 pandemic and to be well-prepared for future similar scenarios.

Acknowledgements The authors acknowledge the U.S. National Institute of Health grant \# R25TW010026 for support of this work.

\section{Declarations}

Conflict of interest The authors certify that they have no affiliations with or involvement in any organization or entity with any financial interest (such as honoraria; educational grants; participation in speakers' bureaus; memberships; employment; consultancies; stock ownership or other equity interest; expert testimony; or patent-licensing arrangements) or nonfinancial interest (such as personal or professional relationships, affiliations, knowledge or beliefs) in the subject matter or materials discussed in this manuscript.

Research Involving Human Participants and/or Animals This work did not involve any human participants or animals. 
Informed Consent No human participants were involved in this work, so no consent form was required.

\section{References}

Abdul-Rahman, M. S. (2009). The Meaning And Explanation of The Glorious Qur'an (Vol 8) 2nd Edition (2nd ed., Vol. 8). MSA Publication Limited.

Al-Balas, Q. A., Dajani, R., \& Al-Delaimy, W. K. (2019). Traditional Islamic approach can enrich CRISPR twins debate. Nature, 566(7745), 455. https://doi.org/10.1038/d41586-019-00665-1

Al-Balas, Q., Dajani, R., \& Al-Delaimy, W. K. (2020). The ethics of gene editing from an Islamic perspective: A focus on the recent gene editing of the Chinese twins. Science and Engineering Ethics, 26(3), 1851-1860. https://doi.org/10.1007/s11948-020-00205-5

Al-Bar, M., \& Chamsi-Pasha, H. (2015). Contemporary Bioethics. Springer. https://doi.org/10.1007/ 978-3-319-18428-9

Al-Izz bin Abdul Salam. (2019). Qawaid al-Ahkam fi Masalih al-Anam. Beirut: Dar al-Ma'rifah.

Bearman, P. J., Bianquis, T., Bosworth, C. E., Van Donzel, E., \& Heinrich, W. S. P. (2002). The encyclopedia of Islam. Leiden: Brill.

Campbell, D., \& Busby, M. (2020). 'Not fit for purpose': UK medics condemn COVID-19 protection. The Guardian: UK edition. (https://www.theguardian.com/society/2020/mar/16/not-fit-for -purpose-uk-medics-condemn-COVID-19-protection).

Carey, L. B., Cohen, J., Koenig, H. G., \& Gabbay, E. (2021). COVID-19, Islam and Christianity. Journal of Religion and Health, 60(2), 621-624. https://doi.org/10.1007/s10943-021-01228-3

CSSE. (2021). COVID-19 Dashboard. Center for Systems Science and Engineering. John Hopkins University. https://coronavirus.jhu.edu/map.html

Emanuel, E. J., Persad, G., Upshur, R., Thome, B., Parker, M., Glickman, A., et al. (2020). Fair allocation of scarce medical resources in the time of Covid-19. The New England Journal of Medicine, 382(21), 2049-2055. https://doi.org/10.1056/NEJMsb2005114

Hashmi, F. K., Iqbal, Q., Haque, N., \& Saleem, F. (2020). Religious Cliché and Stigma: A brief response to overlooked barriers in COVID-19 management. Journal of Religion and Health, 59(6), 26972700. https://doi.org/10.1007/s10943-020-01063-y

John, L., Esposito, ed. (2014). "Ijtihad". The Oxford Dictionary of Islam. Oxford: Oxford University Press.

Kuhn, A. (2020). How A South Korean city is changing tactics to tamp down its COVID-19 Surge. NPR. https://choice.npr.org/index.html?origin=https://www.npr.org/sections/goatsandsoda/2020/03/10/ 812865169/how-a-south-korean-city-is-changing-tactics-to-tamp-down-its-covid-19-surge

Modell, S. M., \& Kardia, S. (2020). Religion as a health promoter during the 2019/2020 COVID outbreak: view from detroit. Journal of Religion and Health, 59(5), 2243-2255. https://doi.org/10. 1007/s10943-020-01052-1

Rabb, I. A. (2009). "Ijtihād". In J. L. Esposito (Ed.), The Oxford Encyclopaedia of the Islamic World. Oxford: Oxford University Press.

Razzak, J. A., Khan, U. R., Azam, I., Nasrullah, M., Pasha, O., Malik, M., \& Ghaffar, A. (2011). Health disparities between Muslim and non-Muslim countries. Eastern Mediterranean Health Journal, 17(9), 654-664.

Strategies for Optimizing the Supply of N95 Respirators. (2021). Center for Disease Control and Prevention. https://www.cdc.gov/coronavirus/2019-ncov/hcp/respirators-strategy/index.html

Vergano, M., Bertolini, G., Giannini, A., Gristina, G. R., Livigni, S., Mistraletti, G., Riccioni, L., \& Petrini, F. (2020). Clinical ethics recommendations for the allocation of intensive care treatments in exceptional, resource-limited circumstances: The Italian perspective during the COVID-19 epidemic. Critical Care (London, England), 24(1), 165. https://doi.org/10.1186/s13054-020-02891-w

Yoosefi Lebni, J., Ziapour, A., Mehedi, N., \& Irandoost, S. F. (2021). The role of clerics in confronting the COVID-19 crisis in Iran. Journal of Religion and Health. https://doi.org/10.1007/ s10943-021-01295-6

Zohaib, A., \& Arzoo, A. (2021). COVID-19: a study of islamic and scientific perspectives. Theology and Science, 19(1), 32-41. https://doi.org/10.1080/14746700.2020.1825192

Publisher's Note Springer Nature remains neutral with regard to jurisdictional claims in published maps and institutional affiliations. 